\title{
Degradation of Carbofuran in Contaminated Soil by Immobilized Laccase
}

\author{
Xin Wang', Li Liu², Mengqin Yao', Huiwen Zhang $^{3}$, Jia Bao ${ }^{1 *}$ \\ ${ }^{1}$ School of Science, Shenyang University of Technology, Shenyang 110870, China \\ ${ }^{2}$ Graduate School of Engineering, Kochi University of Technology, Kochi 782-0003, Japan \\ ${ }^{3}$ School of Science, Shenyang University of Technology, Shenyang 110870, China \\ ${ }^{4}$ Institute of Applied Ecology, Chinese Academy of Sciences, Shenyang110016, China \\ ${ }^{5}$ School of Science, Shenyang University of Technology, Shenyang 110870, China
}

Received: 2 November 2016

Accepted: 11 January 2017

\begin{abstract}
The present study used the method of embedding-adsorption to immobilize fungal laccase and to determine the suitable conditions of immobilization by measuring various activities of immobilized laccase. In addition, the immobilized laccase was further employed to repair the carbofuran-contaminated soil, and then the degradation rates of carbofuran were measured under different conditions. The experimental results showed that the appropriate conditions of embedding-adsorption were presented as follows: the weight of powdered active carbon (PAC) was $0.4 \mathrm{~g}$, the concentration of $\mathrm{CaCl}_{2}$ was $1.5 \%$, the volume of crude laccase was $80 \mathrm{ml}$, and the immobilized time was $6 \mathrm{~h}$. After $48 \mathrm{~h}$, the degradation rate of carbofuran in soil could reach almost $86 \%$ by the immobilized laccase. In fact, the artificially polluted soil and polluted soils in the environment have many differences, so the coming experiment will be concentrated directly on contaminated soil based on laboratory studies in order to investigate the influence of various factors on in-situ remediation.
\end{abstract}

Keywords: fungal laccase, carbofuran, immobilization, degradation rate

\section{Introduction}

Carbofuran (2,3-dihydro-2,2-dimethyl-7-benzofuranyl methylcarbamate) is a broad spectrum carbamate pesticide that has been used worldwide to control insects, nematodes, and acarids in vegetables, fruits, and forest crops [1]. In soil, carbofuran is moderately persistent with a half-life of up to 110 days. Its good water solubility $(700 \mathrm{mg} / \mathrm{L}$ at $25^{\circ} \mathrm{C}$ ) and low adsorption (mean Koc of 29.4) result in the contamination of soil [2-6]. Carbofuran was first

*e-mail: baojia@sut.edu.cn used by the American FMC company in 1968, and China began to register this compound in 1986. The pollution areas of carbofuran in China are found to the northeast, in the Yangtze River, and the coastal areas of the vast plain farming area. These areas are the main producing regions of spring wheat, soybean, corn, cotton, rice, grain, and other crops. Carbofuran has only rarely been applied in western China.

Carbofuran can be efficiently degraded through a biodegradation process, and several metabolites also have been identified [7-9]. As a kind of oxidoreductive enzyme, the laccase can catalyze the oxidation of a broad range of organic compounds such as polyphenols, 
2,2'-azinobis (3-ethylbenzothiazoline-6-sulfonic acid) (ABTS), aromatic compounds, etc. [10-12]. Laccase (EC.1.10.3.2), namely hydroquinone oxidase, is a class of $\mathrm{Cu}$-containing polyphenol oxidase. It is a type of protein found in Rhus vernicifera by Yoshida in 1883, which can catalyze immobilized paint [13]. More than a decade later, Bertrand also found this enzyme in the fungi and named it laccase [14]. Laccases are widely distributed in woodrotting fungi, and some have been derived from plants, bacteria, and insects [15]. Compared to other kinds of laccase, fungal laccase has received much attention for its intensive applications [16]. Previous studies have proved that laccase has strong stability and broad substrate specificity, and many studies have shown the process of laccase catalysis [16].

With the rapid development of immobilized enzyme technology, contemporary immobilized enzyme technology has been applied widely in the degradation of pollutants [17-18], biofuel cells [19-20], residue detection [21-22], and other relevant areas. Ma et al. [23] extracted crude enzymes from HB-5 and immobilized enzyme made from crude enzyme on sodium alginate, and the two methods were introduced to atrazine-polluted soils to evaluate the degrading ability for practical use. Results showed, at $144 \mathrm{~h}$, that only about $10 \%$ of the initially applied amount of atrazine was left in the two soils. Although crude and immobilized enzyme could be used, the immobilized enzyme is preferred for its stability. Rhodococcus sp. and Pseudomonas sp. bioremediation experiments were carried out using free and immobilized cells on natural carrier material (corncob powder) in order to evaluate the feasibility of its use in the bioremediation of hydrocarbon-contaminated soils. When the cells were properly adsorbed on the porous matrix, immobilization became a suitable bioremediation strategy [24]. In reactive industrial dyes, Trametes pubescens and Pleurotus ostreatus were immobilized on polyurethane foam cubes in bioreactors, then used to decolorize three industrial and model dyes at concentrations of 200, 1,000, and 2,000 ppm. Both fungi were able to efficiently decolorize all dyes, even at the highest concentration, and the duckweed test showed a significant reduction $(\mathrm{p} \leq 0.05)$ of toxicity after the decolorization treatment [25].

Wasi et al. immobilized the Pseudomonas fuorescens SM1 strain in calcium alginate beads for remediation of themajor toxicants in Indian water bodies. From the results, a roughly $80 \%$ reduction in the concentration of phenols was observed by immobilized SM1 cells compared with $60 \%$ by the free cells. Also, in the case of the bioremediation of heavy metals, immobilized SM1 cells were found to be more efficient compared with the free cells [26]. But at the same time, the single immobilized method always has its own disadvantages and the activity of the immobilized enzyme is influenced by various environmental factors, leading to a limited range of application to some extent. The adsorption method can be divided into physical adsorption and ionic adsorption. This method uses the carriers with high adsorption capacity and the free enzyme will be adsorbed to the surface of the carriers (the common carriers for this method are silica gel, activated carbon, zeolite, porous glass, quartz sand, and cellulose). The adsorption is a relatively simple and inexpensive method, the carriers can be reused, and the reaction conditions are mild. But the soundness of absorption is poor; if the contact force changes suddenly, the enzyme will easily fall off the carriers [27]. Entrapment could be defined as the physical retention of enzymes in aporous solid matrix. This method will not change the structure of the enzyme, and it can keep the highest activity of the enzyme. However, the immobilized enzyme would lose activity easily because the combination is not very strong. Hence it has always been used together with other immobilized methods [28, 29].

This study combined two kinds of immobilized methods: adsorption and entrapment, improving the activity of immobilized laccase and enhancing the stability of immobilized laccase. The objectives of this study were: 1) to compare the activities of immobilized laccase and non-immobilized laccase, 2) to explore the factors affecting the process of immobilized laccase, and 3) to evaluate the efficiency of immobilized laccase applications on soil remediation for carbofuran contamination.

\section{Materials and Methods}

\section{Chemicals and Equipment}

The specific white-rot fungi were domesticated and trained in the microbiological laboratory of Shenyang University of Technology. The soils without carbofuran were obtained from the campus. The carbofuran was acquired from Zhenjiang Jiansu Pesticide Chemical Co., Ltd (China). Sodium alginate was purchased from Tianjin Bodi Chemical Co., Ltd (China). 2,2'-azinobis (3-ethylbenzothiazoline-6-sulfonic acid) (ABTS) were purchased from Ruibio (Germany). Glutaraldehyde (AR) was purchased from Sinopharm Chemical Reagent Co., Ltd, China. Ultraviolet-visible spectrophotometer (EOK UV721, China) was used to determine laccase activity. High-performance liquid chromatography (HPLC, Agilent 1260 , Singapore) was used to determine the carbofuran degradation rate.

\section{Preparation of Crude Laccase}

A certain quantity of straws (each about $3 \mathrm{~cm} \mathrm{long)}$ was weighed into a conical flask, then water was added to soak for one day and the wet straws were sterilized at high temperature and high pressure for $30 \mathrm{~min}$. After cooling, the straws were used as raw material of producing enzyme culture medium. We grafted white-rot fungi (Lenzites betulinus) into this culture medium and fostered it in an incubator at $26^{\circ} \mathrm{C}$, then added $100 \mathrm{ml}$ aseptic abstract liquid and soaking-draw under $26^{\circ} \mathrm{C}$ and 120 revolutions per minute (rpm) for $24 \mathrm{~h}$. For removing the impurity, the mixture was centrifuged for $15 \mathrm{~min}$ at 4,000 rpm and the supernatant was collected as crude laccase. 


\section{Immobilization Procedure}

We weighed $0.4 \mathrm{~g}$ sodium alginate into $20 \mathrm{ml}$ distilled water, which was then heated at $60^{\circ} \mathrm{C}$ until the compounds became colloidal solution. PAC was then taken into colloidal solution. After mixing, the mixture was dropped into $\mathrm{CaCl}_{2}$ by a special granulator and put into the oscillator at $120 \mathrm{rpm}$ and $25^{\circ} \mathrm{C}$ for $4 \mathrm{~h}$. Later, the carriers were taken out and washed by distilled water repeatedly until the residual $\mathrm{CaCl}_{2}$ was cleaned. Finally, the carriers were put in $250 \mathrm{ml}$ free laccase for immobilization under $120 \mathrm{rpm}$ at $25^{\circ} \mathrm{C}$. After immobilization, the residual free laccase on the surface of carriers was cleaned, and the activity of immobilized laccase was determined.

\section{Determining Free Laccase Activity}

ABTS was used to determine the activity of free laccase with $2 \mathrm{ml}$ of reaction solution containing $200 \mu \mathrm{L}$ of $500 \mathrm{mM} \mathrm{C}_{3} \mathrm{H}_{4} \mathrm{O}_{4}-\mathrm{C}_{3} \mathrm{H}_{2} \mathrm{O}_{4} \mathrm{Na}_{2}(\mathrm{pH}=4.5), 100 \mu \mathrm{L}$ of $20 \mathrm{mM}$ ABTS, $1,500 \mu \mathrm{L}$ of $\mathrm{H}_{2} \mathrm{O}$, and $0.2 \mathrm{ml}$ of laccase liquid. We took the reaction solution into HPLC and started the reaction at $28^{\circ} \mathrm{C}$, then increased the absorbance to $420 \mathrm{~nm}$ during $3 \mathrm{~min}$. The measurement data were used to calculate the free laccase activity. One unit $(U)$ of laccase activity was defined as the amount of laccase used for catalytic oxidation of $1 \mu \mathrm{M}$ ABTS after $1 \mathrm{~min}$.

The free laccase activity was calculated using the following formula:

$$
U=\frac{\Delta A \times V \times 1000 \times V_{1}}{\Delta \mathrm{t} \times \varepsilon_{420} \times V_{0} \times l \times m_{s}}
$$

...where $\Delta A$ was the increasing absorbance during $3 \mathrm{~min}$, $V$ was reaction solution, $V=2 \mathrm{ml}$ and $V_{1}$ was the sterile leach liquor, $t$ was $3 \mathrm{~min}, \boldsymbol{\varepsilon}_{420}=3.6 \times 10^{3} \mathrm{~L} \cdot \mu \mathrm{mol}^{-1} \cdot \mathrm{cm}^{-1}, V_{0}$ was laccase liquid, $\mathrm{V}_{0}=0.2 \mathrm{ml}, l$ was the inner diameter of cuvette, $l=1 \mathrm{~cm}$, and $m_{\mathrm{s}}$ was the quality of the medium.

\section{Determining Immobilized Laccase Activity}

To determine the activity of immobilized laccase, the study used the same method --- ABTS, weighing $0.1 \mathrm{~g}$ immobilized laccase into beaker, $1.8 \mathrm{ml}$ of reaction solution containing $200 \mu \mathrm{L}$ of $500 \mathrm{mM} \mathrm{C}_{3} \mathrm{H}_{4} \mathrm{O}_{4}$ $\mathrm{C}_{3} \mathrm{H}_{2} \mathrm{O}_{4} \mathrm{Na}_{2}(\mathrm{pH}=4.5), 100 \mu \mathrm{L}$ of $20 \mathrm{mM} \mathrm{ABTS}$, and $1,500 \mu \mathrm{L}$ of $\mathrm{H}_{2} \mathrm{O}$. We mixed the reaction solution for $2 \mathrm{~min}$ at $28^{\circ} \mathrm{C}$, then the supernatant was taken into HPLC and started the reaction, as well as determining free laccase activity and increasing the absorbance to $420 \mathrm{~nm}$ during $3 \mathrm{~min}$. Measurement data was used to calculate the immobilized laccase activity. The activity was calculated by the following formula:

$$
U i=\frac{\Delta A \times V \times 1000}{\Delta \mathrm{t} \times \varepsilon_{420} \times M_{0} \times 1}
$$

...where $\Delta A$ was increment of absorbance during $3 \mathrm{~min}$, $V$ was $2 \mathrm{ml}$ of reaction solution, $t$ was $3 \mathrm{~min}, M_{0}$ was $0.1 \mathrm{~g}$ immobilized laccase, and $U i$ was the activity of immobilized laccase.

\section{Preparation of Carbofuran-Contaminated Soil}

After sampling, the soil was filtered through 20 mesh under room temperature. Carbofuran was weighed into a volumetric flask $(500 \mathrm{ml})$, making up to the mark with water and shaking thoroughly. Then this solution was taken into $300 \mathrm{~g}$ soil and water was added for fully mixing to prepare the artificial carbofuran-contaminated soil. After drying, $15 \mathrm{~g}$ soil was taken out and made into 1:3 of slurry with $45 \mathrm{ml}$ water.

\section{Degradation of Carbofuran by Immobilized Laccase}

We weighed $15 \mathrm{~g}$ contaminated soil into $45 \mathrm{ml}$ water for making the contaminated slurry, then put some immobilized laccase in the slurry and set the degradation conditions of $25^{\circ} \mathrm{C}$ and $120 \mathrm{rpm}$, and the degradation rates of carbofuran were measured every $8 \mathrm{~h}$.

\section{Conditions of HPLC}

The mobile phase was prepared with methyl alcohol and distilled water $(78: 22, \mathrm{v} / \mathrm{v})$. UV wavelength was set to $280 \mathrm{~nm}$ at room temperature. The sample size was $10 \mathrm{um}$ at a rate of $1.2 \mathrm{ml} / \mathrm{min}$ and the retention time was $11 \mathrm{~min}$.

\section{Data Processing}

Microsoft Excel was applied to process all the experimental data. SPSS 17.0 (SPSS Inc., Chicago, IL) was applied for statistical analysis, and $p<0.05$ was considered a significant difference.

\section{Results and Discussion}

The factors affecting laccase immobilization

\section{The Influence of Weight of Powder Activated Carbon (PAC) on the Immobilized Laccase}

According to Fig. 1, the weight of PAC increased with the activity of immobilized laccase, which could be attributable to the adsorption ability of PAC for laccase. At the same time, the weight of PAC (data not shown) also affected the formation of carriers. With the rising weight of PAC, the viscosity of the mixed solution was also increasing, and the high viscosity would make the formation of carriers become hard. When the weight of PAC reached $0.8 \mathrm{~g}$, the mixed solution was difficult to drop from the granulator because of the high viscosity. It could be concluded that the added PAC did not dissolve in the mixed solution - they mainly existed in the form 


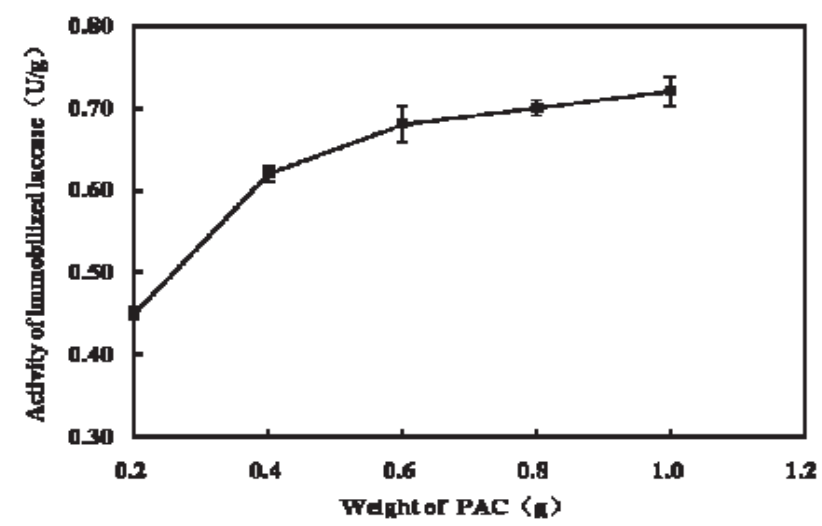

Fig. 1. The influence of PAC weight on immobilized laccase activity.

of tiny powder, and too much tiny powder might lead to "accumulation" in the mixed solution. To comprehensively consider the forming conditions of carriers and the activity of immobilized laccase, it was determined that the appropriate weight of PAC was $0.6 \mathrm{~g}$. Hydrophilic nanoporous PMMA/O-MMT composite microfibrous membrane was used in lacass immobilization, and the immobilized laccase showed better resistance to $\mathrm{pH}$ and temperature changes than that of the free-form laccase, and after 10 successive runs of repeated use, the immobilized laccase still retained $30 \%$ of its initial activity [30].

\section{The Influence of $\mathrm{CaCl}_{2}$ Concentrations on Immobilized Laccase}

In the process of preparing the carrier, $\mathrm{CaCl}_{2}$ was used to consolidate the sodium alginate-activated carbon colloids into carriers. If the concentration of $\mathrm{CaCl}_{2}$ was too low (below 1.0\%), the intensity of carriers would be small and the activity of immobilize laccase would be low. But if the concentration was too high (above $2 \%$ ), the surface of carriers would be full of $\mathrm{Ca}^{2+}$ and it could interact with laccase easily. This reaction would reduce the activity of immobilized laccase. As can be seen from Fig. 2, the activity of immobilized laccase was significantly higher

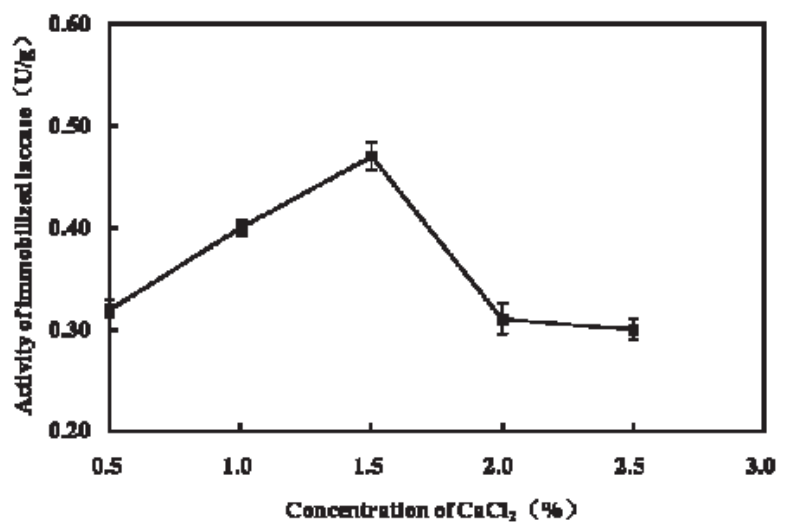

Fig. 2. The influence of $\mathrm{CaCl}_{2}$ concentration on immobilized laccase activity.

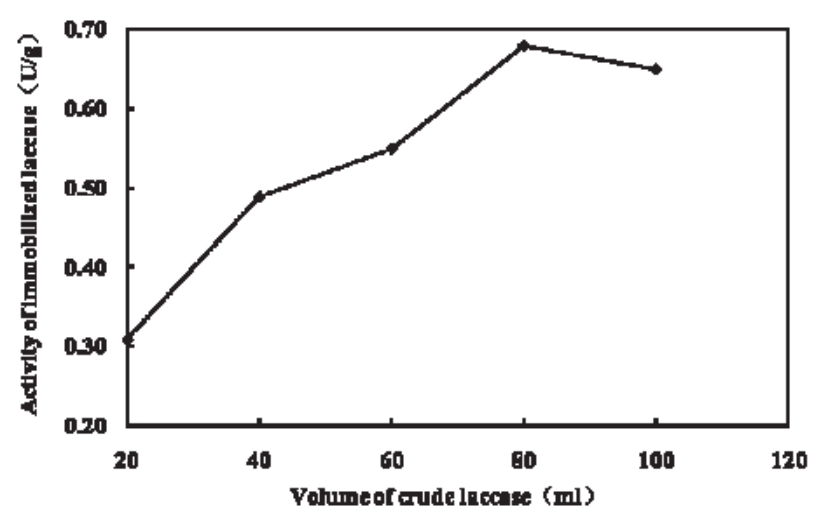

Fig. 3. The influence of crude laccase volume on immobilized laccase activity.

than others when the concentration of $\mathrm{CaCl}_{2}$ was $1.5 \%$. M. S. Mohy Eldin et al. [31] immobilized Glucoamylase ontop-benzoquinone-activated alginate beads by affinity covalent, and investigated the effect of $\mathrm{CaCl}_{2}$ concentrations that resulted in maximum activity being obtained with beads cross-linked at $3 \% \mathrm{CaCl}_{2}$ solution. Indeed, the activity of the covalently immobilized enzyme is almost double its entrapped counterpart.

\section{The Influence of Crude Laccase Volume on Immobilized Laccase}

As shown in Fig. 3, the activity of immobilized laccase changed with different volumes of crude laccase. With the increase of the volume of crude laccase, the immobilized laccase activity showed a rising trend. When the volume was more than $80 \mathrm{ml}$, the carriers may have reached "saturation" and the activity of immobilized laccase tended to stabilize with s slight decline. So $80 \mathrm{ml}$ was chosen as the appropriate volume of crude laccase. Bai et al. [32] studied the effect of the glucoamylase amount added on the activity recovery of covalently immobilized enzyme onto hydrophilic bead carriers containing epoxy groups. They found that the maximum activity recovery and retained activity percentage could reach $78 \%$ when

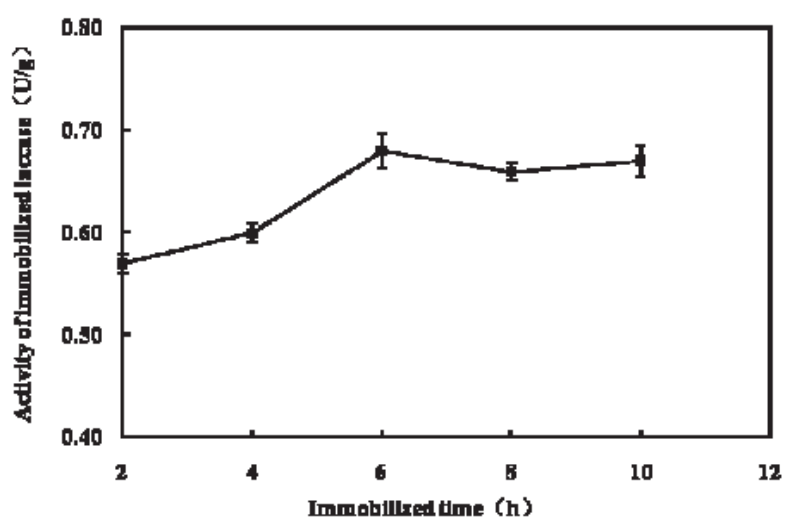

Fig. 4. The influence of immobilized time on immobilized laccase activity. 


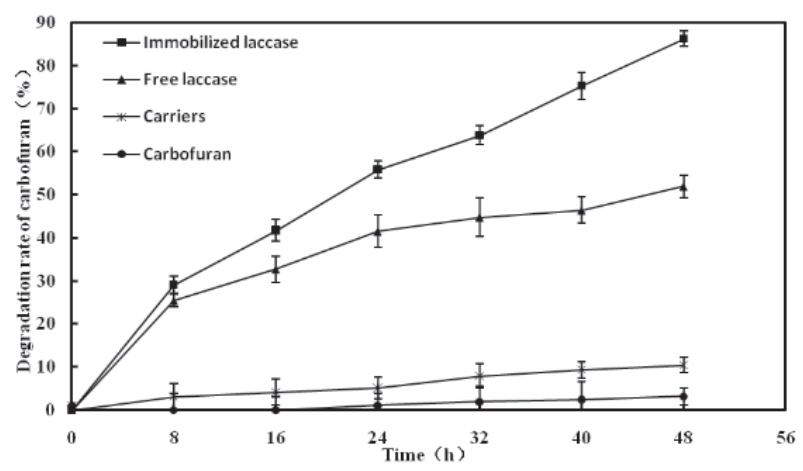

Fig. 5. The influence of immobilized laccase on carbofuran degradation.

the enzyme-adding amount was $0.5 \mathrm{mg}$ with $50 \mathrm{mg}$ of the carrier.

\section{The Influence of Immobilized Time on the Immobilized Laccase}

With the extension of immobilized time, the activity of immobilized laccase showed an increasing trend, but this tendency was indistinctive (Fig. 4). After training for $6 \mathrm{~h}$, the activity did not increased with the time gone. It could be inferred that there is not a close relationship between the activity of immobilized laccase and immobilized time. Previous studies [31] show that the change of cross-linking time had a significant effect on the activity of immobilized enzyme. It is clear that the activity of covalently immobilized enzyme increases by about $30 \%$ with time increase from 30 to $180 \mathrm{~min}$, while its entrapped counterpart does not respond effectively under the same conditions. Accordingly, the percentage of activity increment of covalently immobilized enzyme to an entrapped one ranged from $58 \%$ to $98 \%$ at 30 to 180 min cross-linking time.

The Efficacy of Immobilized Laccase for Remediation of Carbofuran-Polluted Soils

\section{The Influence of Immobilized Laccase on the Degradation of Carbofuran}

Fig. 5 shows that laccase degradation ability was improved significantly $(p<0.05)$ by immobilization, and the carriers also had a certain degree of adsorption. After $48 \mathrm{~h}$, the degradation rates under different conditions are detailed as below: the degradation rates of carbofuran by immobilized laccase, free laccase, and carrier were $83.2 \%$, $52.0 \%$, and $10.4 \%$ respectively. In addition, the carbofuran sample was $3.2 \%$.

\section{The Influence of Environmental Parameters on the Degradation Rate of Carbofuran}

As in Fig. 6, the degradations of immobilized laccase and free laccase were different $(p<0.05)$ under

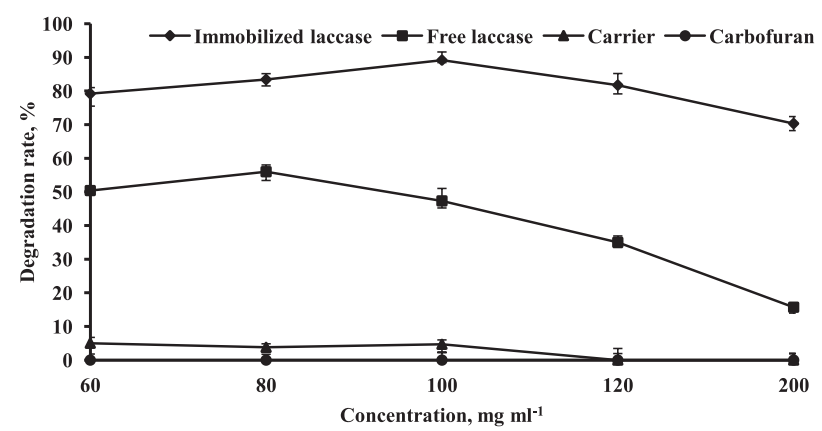

Fig. 6. The influence of initial concentration on the rate of carbofuran degradation.

the experimental range, but the degradations have the same changing trend and increased with the rising concentration. When the concentration was set to $120 \mathrm{mg} / \mathrm{ml}$, the degradation rate declined slightly and showed that a high initial concentration above $200 \mathrm{mg} / \mathrm{ml}$ might inhibit the catalysis activity of laccase. In the last century, many studies [33] have used immobilized methods to degrade organic compounds in the environment. Nawaz et al. [34] immobilized cells of a Pseudomonas sp.- and Xanthomonas maltophilia-degraded acrylamide. Wiesel et al. [35] immobilized mixed bacterial culturedegraded polycyclic aromatic hydrocarbons (PAH). With the development of immobilization technology and genetic engineering, the repair methods of immobilized cells will be more and more extensive.

The results of degradation rates affected by $\mathrm{pH}$ are shown in Fig. 7. The degradation rates were all over $60 \%$ under the range of $\mathrm{pH}$, but the degradation rate of $\mathrm{pH}<7$ was obviously higher in others, showing us that the used laccase was more suitable for catalytic reaction in an acidic environment. Based on SPSS analysis, the influences of immobilized laccase and free laccase on $\mathrm{pH}$ had significant differences $(p<0.05)$. Similarly, Palvannan et al. [36] used bacterial and fungal laccase to degrade the high concentrations of micropollutants, determing that the laccase showed highest activities under acidic conditions.

As shown in Fig. 8, when the temperature was set to $15^{\circ} \mathrm{C}, 20^{\circ} \mathrm{C}, 25^{\circ} \mathrm{C}, 30^{\circ} \mathrm{C}$, and $35^{\circ} \mathrm{C}$ the immobilized laccase had strong degradation ability. After immobilization,

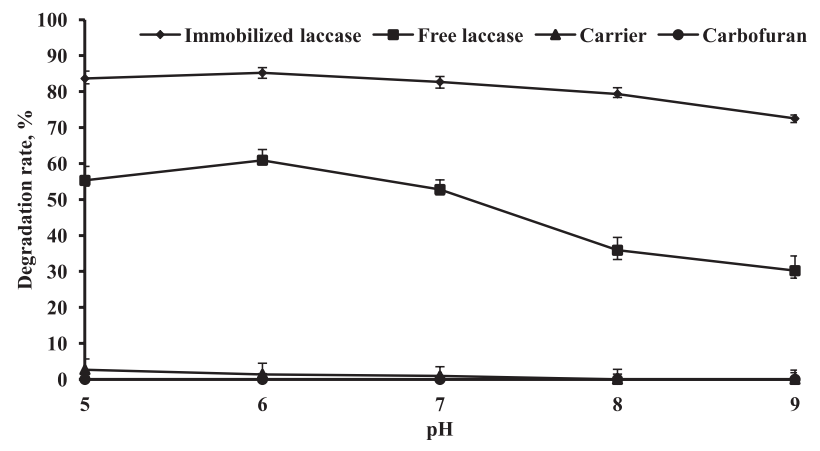

Fig. 7. The influence of $\mathrm{pH}$ on the degradation rate of carbofuran. 


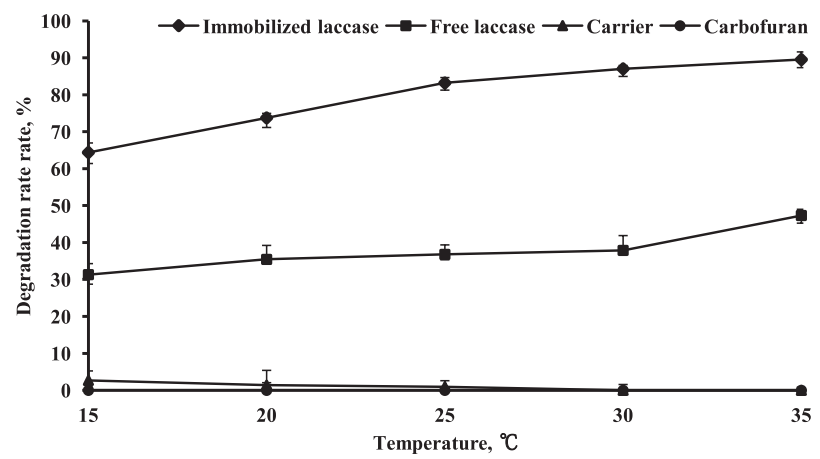

Fig. 8. The influence of temperature on the degradation rate of carbofuran.

the laccase could adapt to higher temperature, so the immobilized laccase could be used under a broad temperature range. Besides the advantages of immobilization at different temperatures, for example, we saw higher enzyme-support reactivity [37], more possibilities of getting an intense multipoint covalent attachment [38], and more rapid immobilization [37]. But there might be some problems to be considered, for example stability of enzyme, stability of the active groups on support, and even stability of the support itself. So different enzymes should be immobilized by their activity to choose the appropriate temperature.

For different kinds of laccase, the training conditions were also different. However, it could not be ignored that only crude laccases were acquired and determined in the training process, while the purifications were not implemented in the experiment. Jaiswal et al. [39] studied the purification of laccase from papaya leaves by a twostep procedure, including heat treatment and con-aaffinity chromatography, to obtain some information about the characteristics of the purified laccase, such as the purified laccase exhibiting acidic and alkaline $\mathrm{pH}$ optima of 6.0 and 8.0 with the non-phenolic substrate (ABTS) and phenolic substrate (catechol), respectively.

The immobilized method adopted by this study was the embedding-adsorption method. Previous studies [28, 29, 38-40] have shown that different immobilized methods have different processes, and the immobilized process was influenced by different factors. Palvannan et al. [41] immobilized the laccase on the zein polyurethane nanofiber, and studied the application in phenyl urea herbicide chloroxuron. They also got the result that the immobilized laccase has better $\mathrm{pH}$ and thermal stability than the free laccase.

This study used artificially polluted soil for remediation (ex-situ remediation). In fact, the artificially polluted soil and polluted soils in the environment have many differences, for example some other natural microbial enzymes in the soil may have some impact on the activity of immobilized enzyme, temperature, humidity, $\mathrm{PH}$, and other environmental factors. The next experiment will be done directly on contaminated soil based on laboratory studies (in-situ remediation). Investigating the influence of various factors on in-situ remediation should be the focus of future research.

\section{Conclusions}

In the present study, the immobilized laccase was used to degrade the carbofuran and the appropriate degradation conditions, including the initial concentration of $100 \mathrm{mg} / \mathrm{ml}, \mathrm{pH}$ of 6 , and temperature of $30^{\circ} \mathrm{C}$. Bioremediation for its high efficiency, safety, low cost, no two pollution has great potential and prospects for development, but the microbes are living organisms that need to have appropriate living conditions, and the bioremediation process is usually better than the physical and chemical repair process, which is slow, and the difference in different regions is large, meaning that repair has restricted the application of the field of bioremediation. Bioaugmentation can integrate the advantages of various immobilized microbial methods into one body, which has incomparable advantages compared with other single immobilized technologies. In this study, the laccase system has the characteristics of high microbial activity, high density of laccase in unit space, and tight cross-linking, but stability is not good and is vulnerable to environmental impact. While embedding into the protective structure can be a good solution to this problem, not only can we put the enzyme into an adverse environment to maintain activity, but we can put the enzyme in the process of drying and storage invariance.

\section{Acknowledgements}

This research is funded by the National Nature Science Foundation of China (No. 31670515) and the National Nature Science Foundation of China (No. 21507092).

\section{References}

1. CHAPAlamadugu S., CHAUdhry G.R. Microbiological and biotechnological aspects of metabolism of carbamates and organophosphates. Crit Rev Biotechnol. 12 (5-6), 357, 1992.

2. ODUKKATHIL G., VASUDEVAN N. Toxicity and bioremediation of pesticides in agricultural soil. Reviews in Environmental Science and Bio/Technology. 12 (4), 421, 2013.

3. OTIENO P.O., LALAH J.O., VIRANI M., JONDIKO I.O., SCHRAMM K.W. Carbofuran use and abuse in Kenya: residues in soils, plants, water courses and the African white-backed vultures (Gyps africanus) found dead. Environmentalist. 31 (4), 382, 2011.

4. TARIQ M.I., AFZAL S., HUSSAIN I. Degradation and persistence of cotton pesticides in sandy loam soils from Punjab, Pakistan. Environ. Res. 100 (2), 184, 2006.

5. FARAHANI G.H.N., SAHID I.B., ZAKARIAZ., KUNTOM A., OMAR D. Study on the Downward Movement of Carbofuran in Two Malaysian Soils. Bull. Environ. Contam. Toxicol. 81 (3), 294, 2008. 
6. DIXIT B.S., BANERJI R. Carbofuran residue in water, soil, and trapa fruits, after field application. Bull. Environ. Contam. Toxicol. 52 (5), 772, 1994.

7. NGUYEN T.P.O., HELBLING D.E., BERS K., FIDA T.T., WATTIEZ R., KOHLER H.P., SPRINGAEL D., DE MOT R. Genetic and metabolic analysis of the carbofuran catabolic pathway in Novosphingobium sp. KN65.2. Appl. Microbiol. Biotechnol. 98 (19), 8235, 2014.

8. SILAMBARASAN S., ABRAHAM J. Ecofriendly Method for Bioremediation of Chlorpyrifos from Agricultural Soil by Novel Fungus Aspergillus terreus JAS1. Water, Air, Soil Pollut. 224 (1), 1, 2013.

9. RUIZ-HIDALGO K., CHIN-PAMPILLO J.S., MASÍSMORA M., CARAZO-ROJAS E., RODRÍGUEZRODRÍGUEZ C.E. Optimization of a Fungally Bioaugmented Biomixture for Carbofuran Removal in OnFarm Biopurification Systems. Water, Air, Soil Pollut. 227 (1), 1, 2016.

10. PUNNAPAYAK H., PRASONGSUK S., MESSNER K., DANMEK K., LOTRAKUL P. Polycyclic aromatic hydrocarbons (PAHs) degradation by laccase from a tropical white rot fungus Ganoderma lucidum. Afr. J. Biotechnol. 8 (21), 5897, 2009.

11. RUSSO M.E., GIARDINA P., MARZOCCHELLA A. Assessment of anthraquinone-dye conversion by free and immobilized crude laccase mixtures. Enzyme Microb. Technol. 42 (6), 521, 2008.

12. BAUTISTA L.F., MORALES G., RAQUEL S. Immobilization strategies for laccase from Trametes versicolor on mesostructured silica materials and the application to the degradation of naphthalene. Bioresour. Technol., 101 (22), 8541, 2010.

13. YOSHIDA H. Chemistry of lacquer (urushi) part I. J. Chem. Soc. 43, 427,1883.

14. BERTRAND G. Simultaneous existence of laccase and tyrosinase in the secretion of some fungi. C.R.Hebd. Seances Acad. Sci., 123, 463, 1896 [In French].

15. GIARDINA P., FARACO V., PEZZELLA C., PISCITE A., V ANHULLE S., SANNIA G. Laccase: a never-ending story. Cell. Mol. Life.Sci. 67(3), 369, 2010.

16. FERNÁNDEZ-FERNÁNDEZ M., SANROMÁN M.Á., MOLDES D. Recent developments and applications of immobilized laccase. Biotechnol. Adv. 31 (8), 1808, 2013.

17. LANGLEY W.G., WU, J.S., CHAO, A.C. Reaction kinetics of immobilized-cell denitrification. I: background and model development. J. Environ. Eng. 127 (8), 682, 2001.

18. SONGULASHVILI G., JIMENÉZ-TOBÓN G.A., JASPERS C., PENNINCKX M.J. Immobilized laccase of Cerrena unicolor for elimination of endocrine disruptor micropollutants. Fungal.Biol., 116 (8), 883, 2012.

19. MERLE G. Electrode biomaterials based on immobilized laccase. Application for enzymatic reduction of dioxygen. Mater. Sci. Eng., C. 28 (5-6), 932, 2008.

20. TAMAKI T., HIRAIDE A., ASMAT F.B., OHASHI H., ITO T., YAMAGUCHI T. Evaluation of immobilized enzyme in a high-surface-area biofuel cell electrode made of redoxpolymer-grafted carbon black. Ind. Eng. Chem. Res., 49 (14), 6394, 2010.

21. ZHENG Y.H., HUA T.C., SUN D.W., XIAO J.J.,XUA F., WANG F.F. Detection of dichlorvos residue by flow injection calorimetric biosensor based on immobilized chicken liver esterase. J. Food Eng., 74 (1), 24, 2006.

22. YAROPOLOV A.I., SHLEEV S.V., MOROZOVA O.V., ZAITSEVA E.A., MARKO-VARGA G., EMNEUS J., GORTON L. An amperometric biosensor based on laccase immobilized in polymer matrices for determining phenolic compounds. J. Anal. Chem., 60 (6), 553, 2005.

23. MA T.T. ZHU L.S., WANG J.H., WANG J., XIE H., SU J., ZHANG Q.M., SHAO B. Enhancement of atrazine degradation by crude and immobilized enzymes in two agricultural soils. Environmental Earth Sciences. 64 (3), 861,2011

24. RIVELL V., FRANZETTI A., GANDOLFI I., CORDONI S., BESTETTI G. Persistence and degrading activity of free and immobilised allochthonous bacteria during bioremediation of hydrocarbon-contaminated soils. Biodegradation, 24 (1), $1,2013$.

25. CASIERI L., VARESE G. C., ANASTASI A., PRIGIONE V., SVOBODOVÁ K., FILIPPELO MARCHISIO V., NOVOTNÝ Č. Decolorization and detoxication of reactive industrial dyes by immobilized fungi Trametes pubescens and Pleurotus ostreatus. Folia Microbiol. 53 (1), 44, 2008.

26. WASI S., TABREZ S., AHMAD M. Suitability of Immobilized Pseudomonas fluorescens SM1 Strain for Remediation of Phenols, Heavy Metals, and Pesticides from Water. Water, Air, Soil Pollut., 220 (1), 89, 2011.

27. FANG H., HUANG J., DING L.Y., LI M.T., CHEN Z. Preparation of magnetic chitosan nanoparticles and immobilization of laccase. J Wuhan Univ Technol Mater Sci Ed., 24 (1), 42, 2009.

28. SADIGHI A., FARAMARZI M.A. Congo red decolorization by immobilized laccase through chitosan nanoparticles on the glass beads. J.Taiwan.Inst.Chem.E., 44 (2), 156, 2013.

29. MARGOT J., BENNATI-GRANER C., MAILLARD J., BLÁNQUEZ P., BARRY D.A., HOLLIGER C. Bacterial versus fungal laccase: potential for micropollutant degradation. AMB Express, 3 (1), 1, 2013.

30. WANG Q.Q., PENG L., DU Y.Z., XU J., CAI Y.B., FENG Q., HUANG F.L., WEI Q.F. Fabrication of hydrophilic nanoporous PMMA/O-MMT composite microfibrous membrane and its use in enzyme immobilization. J. Porous Mater., 20 (3), 457, 2013.

31. ELDIN M.S., SEUROR E.I., NASR M.A., TIEAMA H.A. Affinity covalent immobilization of glucoamylase onto $\rho$-benzoquinone-activated alginate beads: II. Enzyme immobilization and characterization. Appl. Biochem. Biotechnol., 164 (1), 45, 2011.

32. BAI Y.X., LI Y.F., WANG M.T. Study on synthesis of a hydrophilic bead carrier containing epoxy groups and its properties for glucoamylase immobilization. Enzyme Microb. Technol., 39 (4), 540, 2006.

33. CASSIDY M.B., LEE H., TREVORS J.T. Environmental applications of immobilized microbial cells: a review. J. Ind. Microbiol. Biotechnol., 16 (2), 79, 1996.

34. NAWAZ M.S., FRANKLIN W., CERNIGLIA C.E. Degradation of acrylamide by immobilized cells of a Pseudomonas sp and Xanthomonas maltophilia. Can. J. Microbiol., 39 (2), 207, 1993.

35. WIESEL L., WÜBKER S.M., REHM H.J. Degradation of polycyclic aromatic hydrocarbons by an immobilized mixed bacterial culture. Appl. Microbiol. Biotechnol., 39 (1), 110, 1993.

36. PALVANNA T., SARAVANAKUMAR T., UNNITHAN A.R., CHUNG N.J. Efficient transformation of phenyl urea herbicide chloroxuron by laccase immobilized on zein polyurethane nanofiber. J. Mol. Catal. B: Enzym., 99 (99), 156, 2014.

37. MATEO C., ABIAN O., BERNEDO M., CUENCA E., FUENTES M. Some special features of glyoxylsupports to immobilize proteins. Enzyme Microb Tech., 37 (4), 456, 2005. 
38. BLANCO R.M., CALVETEJ.J., GUISAN J.M. Immobilization-stabilization of enzymes; variables that control the intensity of the trypsin (amine)-agarose (aldehyde) multipoint attachment. Enzyme Microb Tech., 11( 6), 353, 1989.

39. JAISWAL N., PANDEY V.P., DWIVEDI U.N. Purification of a thermostable alkaline laccase from papaya (Carica papaya) using affinity chromatography. Int. J. Biol.Macromol., 72, 326, 2015.

40. CRISTÓVÃO R.O., TAVAREA A.P.M., BRÍGIDA A.I., LOUREIRO J.M., RUI A.R.B., MACEDO E.A., COELHO
M.A.Z. Immobilization of commercial laccase onto green coconut fiber by adsorption and its application for reactive textile dyes degradation. J. Mol. Catal. B: Enzym., 72 (1-2), 6, 2011.

41. PALVANNA T., SARAVANAKUMAR T., UNNITHAN A.R., CHUNG N.J. Efficient transformation of phenyl urea herbicide chloroxuron by laccase immobilized on zein polyurethane nanofiber. J. Mol. Catal. B: Enzym., 99 (99), 156, 2014. 